\title{
GEOMORPHOLOGY, SEDIMENTOLOGY AND GEOCHEMISTRY IN THE MARINE AREA BETWEEN SIFNOS AND KIMOLOS ISLANDS, GREECE
}

\author{
Karageorgis A.P. ${ }^{1}$, Ioakim Chr. ${ }^{2}$, Rousakis G. ${ }^{1}$, Sakellariou D. ${ }^{1}$, \\ Vougioukalakis G. ${ }^{2}$, Panagiotopoulos I.P. ${ }^{1}$, Zimianitis E. ${ }^{2}$, Koutsopoulou E. ${ }^{2}$, \\ Kanellopoulos Th. ${ }^{1}$, Papatrechas Ch. ${ }^{2}$, Georgiou P. ${ }^{1}$, Xirokostas N. ${ }^{2}$, \\ Stavrakaki I. ${ }^{1}$, Vakalas I. ${ }^{2}$, Morfis I. ${ }^{1}$, Koutsovitis . $^{2}$, Drakopoulou P. ${ }^{1}$, \\ Kyriakidou Ch. ${ }^{1}$ and Marantos I. ${ }^{2}$ \\ ${ }^{1}$ Hellenic Centre for Marine Research, 46.7 km Athens-Sounio Ave., 19013 Anavyssos, Greece, \\ ak@hcmr.gr,rousakis@hcmr.gr,sakell@hcmr.gr,jpanagiot@hcmr.gr,thkan@hcmr.gr, \\ pgeorg@hcmr.gr,istavrakaki@hcmr.gr,gianmor@hcmr.gr,vivi@hcmr.gr,hkyriakid@hcmr.gr \\ ${ }^{2}$ Institute of Geology and Mineral Exploration, $1^{\text {st }}$ Spirou Louis St., Olympic Village, 13677, \\ Acharnae,Greece,ioakim@igme.gr,gvoug@igme.gr,zimianitis@igme.gr,ekoutsop@upatras.gr, \\ papatrechas@windowslive.com,xirikostas@igme.gr,vakalas@upatras.gr. \\ petroskoutsovitis@yahoo.com,marantos@igme.gr
}

\begin{abstract}
An extensive oceanographic survey was conducted in the marine area between Kimolos and Sifnos Islands, a rather poorly-studied sector of the Aegean Sea, in order to gain better understanding of submarine geomorphological features and associated sediment provenance. Multi-beam bathymetry and surface sediment sampling with a box corer were carried out on board $R / V$ Aegaeo, followed by grain-size analysis, $X R D$ and XRF measurements. A large circular depression was identified north of Kimolos reaching a water depth of $743 \mathrm{~m}$, filled with fine-grained sediments. Surface sediment distribution is characterized by gradual decrease in grain-size from silty sand to silt in a $\mathrm{S}-\mathrm{N}$ direction. The mineralogical composition comprises calcite, $\mathrm{Mg}$ calcite, aragonite, dolomite, quartz, K-feldspars, plagioclase, amphiboles and clay minerals. Major sediment provinces identified were: (i) the shallow sector proximal to Kimolos, characterized by higher contents in $\mathrm{Si}, \mathrm{Al}, \mathrm{K}, \mathrm{Rb}$ and $\mathrm{Ba}$; (ii) the deep area west of Sifnos, including the large depression, characterized by higher contents in $\mathrm{Fe}, \mathrm{Ti}, \mathrm{Na}, \mathrm{Mg}, \mathrm{S}, \mathrm{Cr}, \mathrm{Cu}, \mathrm{Ni}, \mathrm{V}, \mathrm{Zn}$; and (iii) the south passage between Kimolos and Sifnos, which exhibits higher $\mathrm{Ca}, \mathrm{S}$, and Sr contents. Manganese enrichment was observed in and around the bathymetric depression, where Mn oxides act efficiently as scavengers of a suite of metals.

Keywords: sediment provenance, depression, carbonate minerals, manganese oxides.
\end{abstract}

\section{Пврі́ $\eta \psi \eta$}

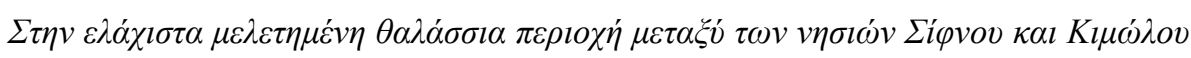

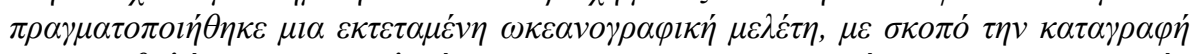

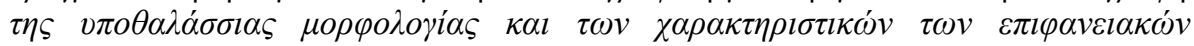

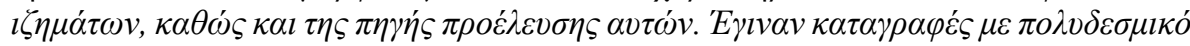

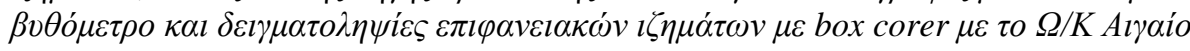




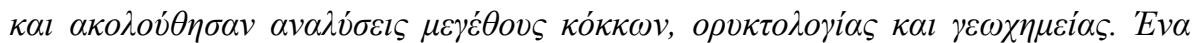

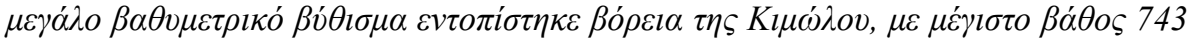

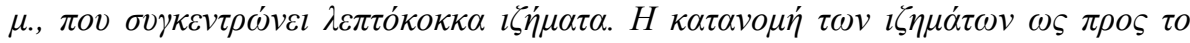

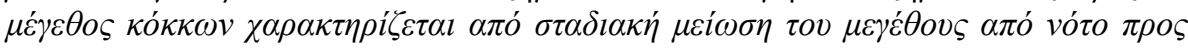

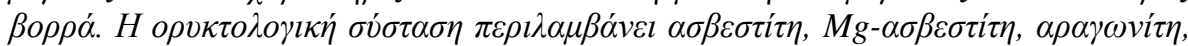

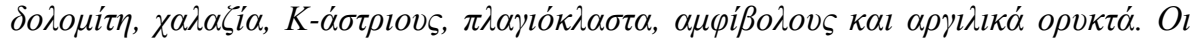

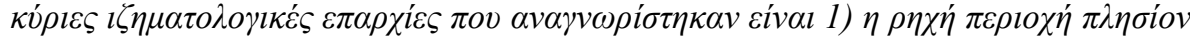

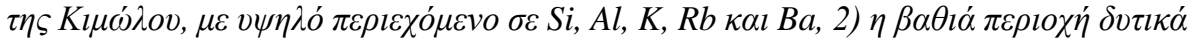

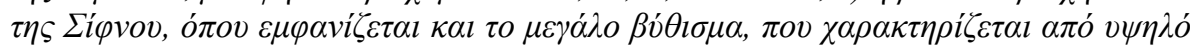

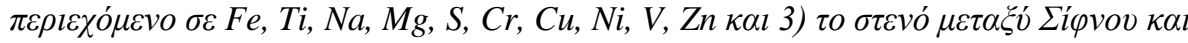

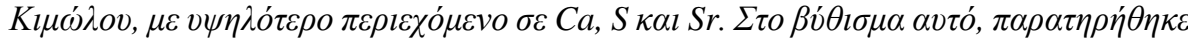

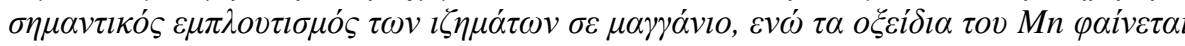

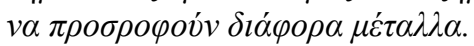

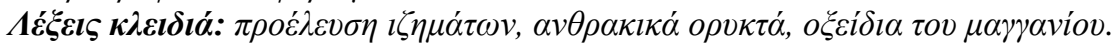

\section{Introduction}

The South Aegean Volcanic Arc is the major geomorphological feature of the entire Aegean Sea, featuring a series of volcanoes as Methana and Milos to the west, and Santorini and Nisyros to the east. Milos and Kimolos islands lie in the westernmost sector the Cyclades Plateau, whereas Sifnos Island lies further to the NE, on a broad shelf characterized generally by water depths $<400 \mathrm{~m}$ (Poulos, 2009). The marine area between the latter islands has been investigated by Piper and Perissoratis (2003) in respect to the sedimentary and tectonic Quaternary evolution, however, the sedimentological features of the area, as well as associated depositional processes of the sediments, are largely unknown.

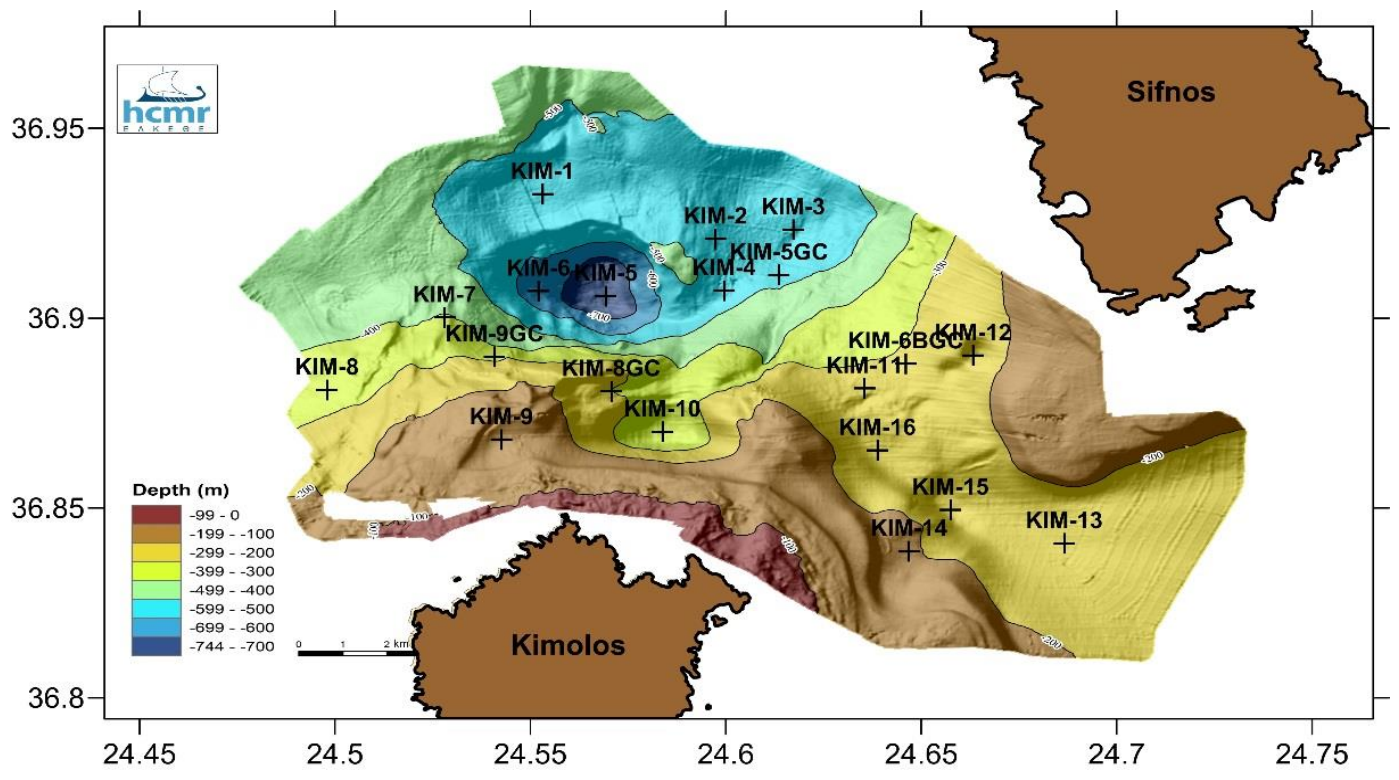

Figure 1 - Sampling stations location superimposed on swath bathymetry map.

The Hellenic Centre for Marine Research (HCMR) and the Institute of Geology and Mineral Explorations (IGME) have been conducting since 2013 a multifaceted oceanographic project in the Aegean Sea named 'Aegean Explorations/YPOTHER'. As part of this project, a cruise (AEX-2) was organized in 2014 in SW Cyclades with initial aim to investigate a prominent submarine depression located between Kimolos and Sifnos; data collected earlier by the Hellenic Hydrographic Service 
and IGME had recorded a semi-circular submarine feature with water depths up to $720 \mathrm{~m}$, some 200 $\mathrm{m}$ deeper than the surrounding seafloor.

Multi-beam bathymetry, seismic profiling, and remotely operated vehicle dives were utilized to provide information on this peculiar geomorphological feature, whereas surface sediments and gravity cores were collected to better understand the geochemical characteristics of the area. Here we present preliminary results on the submarine geomorphology and associated surface sediment properties, documented for the first time. Sediment transport and depositional processes are discussed, whilst sediment provenance is considered in respect to differing island lithology.

\section{Materials and methods}

The oceanographic cruise AEX-2 was carried out between 30 April and 9 May 2014 on board R/V Aegaeo. The bathymetry survey (total length of $250 \mathrm{~nm}$ ) was performed with a hull-mounted SeaBeam 2120 multi-beam echo sounder (frequency of operation: $20 \mathrm{kHz}$; applied half-swath angle: 58-60; maximum received beams: $117-121$; swath overlapping: a minimum of $30 \%$; across-track resolution: <14 m; along-track resolution: <10 m). Several sound velocity profiles, obtained from conductivity-temperature vs depth (CTD) casts at deep sites $(600-630 \mathrm{~m})$ in the study area, were incorporated into the acquisition software of the multi-beam system to calibrate the position and accuracy of recorded depth values. The estimated error in the vertical and horizontal dimension was within $0.5 \%$ and $10 \mathrm{~m}$, respectively.

Sixteen surface sediments $(0-2 \mathrm{~cm})$ were collected by means of a stainless-steel box corer. In addition, 4 gravity core tops $(0-3 \mathrm{~cm})$ were used for geochemical analysis only, due to limited sample quantity. Grain-size measurements were performed with the pipette method, after separation of the $>63 \mu \mathrm{m}$ fraction by wet sieving, and textural sediment classification followed the subdivisions of Folk (1974) (Table 1). The samples were analyzed for the determination of their mineralogical composition using X-Ray diffraction (XRD). The X-Ray diffractometer was a Panalytical X'pertPro with a $\mathrm{Cu} X$-ray tube $\left(\mathrm{K}_{\alpha}\right.$ of $\mathrm{Cu}, \lambda=1.5405 \AA$ ) $)$, graphite monochromator, an applied voltage 30 $\mathrm{kV}$ and a $40 \mathrm{~mA}$ current. The random powder mounts of samples, prepared by back loading, were scanned from $2-70^{\circ} 2 \theta$. Data were evaluated with the XPert High-Score (Version 2004) (Panalytical B.V., Almelo, The Netherlands) and the EVA® software (DIFFRACplus EVA v12.0, Bruker AXS $\mathrm{GmbH}$ ) and managed with the PDF-2 database (International Centre for Diffraction Data, Newtown Square, PA, USA). The clay fraction $(<2 \mu \mathrm{m})$ was separated by settling and oriented glass slides were prepared for the determination of clay minerals. X-Ray diffraction analysis was performed from $2-35^{\circ} 2 \theta$ (i) from air-dried samples, (ii) after ethylene glycol solvation at $60{ }^{\circ} \mathrm{C}$ to ensure maximum saturation and (iii) after heating at $490{ }^{\circ} \mathrm{C}$. The mineral phases were quantified with a standardless Rietveld refinement routine using TOPAS ${ }^{\circledR}$ software, and the quantification errors were less than $1 \%$ (Table 2). Polished thin sections were prepared and examined in the SEM laboratory of IGME, (JEOL JSM-5600 coupled with an Oxford Instruments EDS system), whereas the analysis conditions were $30 \mathrm{keV}$ acceleration voltage, $3 \mathrm{nA}$ beam current and a spot diameter of $10-30 \mu \mathrm{m}$.

Bulk samples were oven dried, ground to a fine powder in a Fritsch motorized mill with agate mortar and balls and were analyzed for their chemical composition in a Panalytical PW-2400 wavelength $\mathrm{X}$-Ray fluorescence analyzer, equipped with Rh-tube. Major elements were determined in fused beads and minor elements in pressed-powder pellets following the procedure of Karageorgis et al. (2005, 2009). Part of the same samples were pulverized to $<200$ mesh in an agate mill, was digested with a mixture of $\mathrm{HCl}-\mathrm{HNO}_{3}-\mathrm{HF}$ acids and were analyzed for a series of trace elements by Inductively Coupled Plasma-Atomic Emission Spectroscopy (ICP-MS). Loss on ignition (LOI) was determined by estimating the weight loss after burning $1 \mathrm{~g}$ of sample for $1 \mathrm{~h}$ at $1000^{\circ} \mathrm{C}$. The geochemical data set comprised also the top (0-4 cm) sediment of four gravity cores (Table 1). 
Table 1 - Grain-size classes and major/minor elemental contents for surface sediments from Kimolos-Sifnos marine area.

\begin{tabular}{|c|c|c|c|c|c|c|c|c|c|c|c|c|c|c|c|c|c|c|c|c|c|c|c|c|c|c|c|c|c|}
\hline Station & pth & nd & silt & ay & $\mathrm{O}_{2}$ & $\mathrm{Al}_{2} \mathrm{O}_{3}$ & $\mathrm{Fe}_{2} \mathrm{O}_{3}$ & $\mathrm{TiO}_{2}$ & $\mathbf{K}_{2} \mathrm{O}$ & $\mathbf{a}_{2} \mathrm{O}$ & $\mathrm{CaO}$ & MgO & $\mathrm{SO}_{3}$ & $\mathrm{P}_{2} \mathrm{O}_{5}$ & MnO & LOI & im & $\mathbf{s}$ & $\mathrm{Ba}$ & Co & $\mathbf{C r}$ & $\mathrm{Cu}$ & Mn & $\mathrm{Ni}$ & $\mathbf{P b}$ & $\mathbf{R b}$ & $\mathrm{Sr}$ & $\mathrm{V}$ & \\
\hline & $\mathrm{m}$ & \multicolumn{16}{|c|}{$\%$} & \multicolumn{12}{|c|}{$\mu \mathrm{g} \mathrm{g}^{-1}$} \\
\hline KIM-1 & 547 & 1. & 94.2 & 4.1 & 5.7 & 7.2 & 9 & 30 & 1.49 & 2.85 & 4.6 & 30 & 702 & 0.119 & 73 & .5 & 1.1 & 17 & 340 & 7 & 94 & 37 & 2700 & 72 & 41 & 62 & 84 & 67 & \\
\hline KIM-2 & 18 & 4.0 & .0 & 4. & 26 & 7.1 & 89 & 324 & 1.49 & 2.86 & 24.7 & 3.19 & 683 & 0.112 & 0.210 & 1.4 & 01.0 & 20 & 374 & 19 & 88 & 34 & 2145 & 71 & 42 & 61 & 883 & 66 & 39 \\
\hline KIM-3 & 575 & 6.1 & 88.4 & 5. & 25.9 & 7.3 & 95 & 0.326 & 1.49 & 3.16 & 24.0 & 3.23 & 0.775 & 0.118 & 0.242 & 31.6 & 101.2 & 17 & 372 & 17 & 84 & 37 & 2365 & 71 & 43 & 61 & 878 & 65 & 93 \\
\hline KIM-4 & 18 & 4.2 & 90.6 & 5. & 25.6 & 7.1 & 2.91 & 0.325 & 1.48 & 2.94 & 24.6 & 3.24 & 0.712 & 0.114 & 0.189 & 31.1 & 100.3 & 20 & 363 & 18 & 82 & 34 & 1828 & 69 & 43 & 61 & 877 & 63 & 90 \\
\hline KIM-5 & 735 & 5.4 & 87.2 & 7.4 & 24.2 & 6.9 & 3.00 & 0.312 & 1.43 & 3.56 & 23.8 & 3.29 & 0.786 & $\mid$\begin{tabular}{|l|l}
$\mid$ \\
$\mid$
\end{tabular} & 0.576 & 32.9 & 100.9 & 23 & 340 & 24 & 89 & 36 & 5833 & 79 & 43 & 59 & 853 & 65 & 93 \\
\hline KIM-6 & 639 & 14.4 & 0.9 & 4. & 22.1 & 7.1 & 2.69 & 0.291 & $\mid$\begin{tabular}{|l}
1.21 \\
\end{tabular} & 2.67 & 26.8 & 3.46 & 0.671 & 0.118 & $\mid 0.169$ & 33.5 & 100.8 & 18 & 302 & 17 & 82 & 36 & 1722 & 68 & 40 & 55 & 896 & 63 & 85 \\
\hline KIM-7 & 83 & 44.2 & 3.7 & 2. & 8.8 & 5.4 & 2.07 & 0.233 & 1.09 & 1.87 & 30.7 & 3.37 & 0.575 & 0.099 & $\mid 0.097$ & 33.0 & 99.3 & 17 & 340 & 11 & 57 & 22 & 1016 & 43 & 31 & 45 & 934 & 50 & 66 \\
\hline KIM-8 & 32 & 35.3 & 2.4 & 2. & 26 & 6.3 & 2.35 & 0.280 & 1.37 & 2.17 & 27.2 & 3.03 & 0.566 & 0.106 & 0.143 & 30.5 & 100.3 & 19 & 458 & 10 & 59 & 24 & 1296 & 45 & 37 & 53 & 914 & 52 & 80 \\
\hline KIM-9 & 173 & 53.2 & .7 & 2 & 2 & 8.0 & 2.50 & 0.229 & 1.32 & 2.14 & 24.7 & 2.47 & 0.566 & 0.081 & 0.110 & 30.0 & 99.4 & 17 & 672 & 11 & 40 & 18 & 1252 & 29 & 33 & 60 & 1347 & 44 & 74 \\
\hline KIM-10 & 367 & 40.0 & .6 & 2. & 3 & 7.5 & 2.65 & 0.314 & 1.65 & 2.45 & 23.5 & 2.37 & 0.610 & 0.103 & 0.113 & 26.4 & 100.1 & 19 & 631 & 12 & 58 & 24 & 1140 & 43 & 37 & 64 & 963 & 57 & 83 \\
\hline KIM-11 & 274 & 41.4 & 9 & 1. & 2 & 5. & 2 & 272 & 1.27 & 2.02 & 28.4 & 2.99 & 0.664 & $\mid \begin{array}{l}\mid \\
\end{array}$ & 0.093 & 30. & 99.8 & 17 & 395 & 10 & 60 & 22 & 965 & 42 & 29 & 50 & 1014 & 49 & 63 \\
\hline KIM-12 & 245 & .5 & 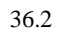 & 1.4 & 23.9 & 5. & 2 & 250 & 1. & 1.92 & 30.1 & 2.75 & 0.589 & 0.093 & 083 & 31.0 & 99.4 & 10 & 323 & 11 & 59 & 19 & 869 & 40 & 18 & 45 & 1204 & 46 & 48 \\
\hline 10 & 253 & 41.3 & 574 & 1.3 & 24.9 & 5. & 2.27 & 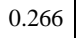 & 1. & 2. & 28.4 & 2.94 & 754 & 0.094 & 7 & Det & 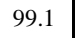 & 15 & 371 & 10 & 62 & 23 & 981 & 42 & 23 & 48 & 1104 & 46 & 55 \\
\hline 10 & & & & 0. & & 1 & & 0.263 & I. & 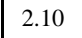 & 23.9 & & 77 & 0.085 & 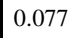 & 20 & 99.3 & 6 & 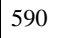 & & 53 & 13 & 821 & 32 & 28 & 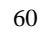 & 11137 & 44 & ( \\
\hline & & & & 2. & & 5.9 & & & 1. & 2. & & & 697 & $\mid 0.099$ & 4 & 2.5 & & 15 & 399 & 11 & 62 & 20 & 836 & 41 & 23 & Jo & 1139 & 47 & (3) \\
\hline & & 列 & & 12. & & t & & 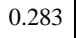 & $\mid$\begin{tabular}{|l}
$\mid$ \\
\end{tabular} & 50 & & & .718 & 0.098 & 0.070 & 2.0 & ( & 19 & 414 & 10 & 62 & 25 & 973 & 42 & 26 & 52 & 1042 & 49 & 01 \\
\hline KIM-5GC & & - & - & - & & 7.2 & & 0.328 & $\mid 1.48$ & 2.05 & 26.2 & & 9 & $\mid$\begin{tabular}{l|l} 
\\
\end{tabular} & 2 & \begin{tabular}{|l|}
29.4 \\
\end{tabular} & 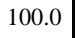 & 20 & 330 & 16 & 79 & 33 & 2182 & 66 & 34 & 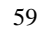 & 921 & 62 & 11 \\
\hline Ning & 202 & - & - & - & 2 & 6.5 & 2 & (1) & $\mid 1.34$ & 1.79 & 27.1 & 2.91 & 605 & $\mid 0.101$ & 098 & 7. & . & 11 & 202 & 0 & 56 & 17 & 473 & 40 & 21 & 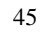 & 61 & 44 & 44 \\
\hline KIVI-дUC & 230 & - & - & - & 31.0 & 8.7 & 2.15 & 0.017 & 1.63 & 1.07 & 25.1 & 2.34 & 0.345 & 0.102 & 0.103 & 26.1 & 年 & 13 & 年 & (3) & 52 & 18 & 440 & 36 & 51 & 55 & 370 & 46 & 61 \\
\hline KIM-9GC & 316 & - & - & - & 26.8 & 6.4 & 2 & 288 & 1.38 & 2. & .5 & 3.12 & 502 & 0.109 & 099 & 28.5 & 99.7 & 18 & 456 & 10 & 56 & 26 & 65 & 41 & 37 & 53 & 72 & 52 & 75 \\
\hline mean & & 30.2 & 0.1 & 3.1 & 20.2 & 0.13 & 2.0 & 0.290 & 1.37 & 2.36 & 26.2 & 2.90 & 0.642 & 0.107 & 0.159 & 30.3 & & 17 & 410 & 13 & 67 & 26 & 1540 & 51 & 34 & 55 & 990 & 54 & 72 \\
\hline dev & & 20.4 & 18.9 & 1.8 & 2.12 & 0.92 & 0.50 & 0.032 & $\mid \begin{array}{l}\mid \\
\end{array}$ & 0.50 & 2.23 & 0.3 & 0.110 & 0.018 & 0.115 & 1.9 & & 3 & 106 & 4 & 15 & 7 & 1193 & 16 & 9 & 6 & 134 & 9 & 15 \\
\hline
\end{tabular}




\section{Results}

\subsection{Submarine geomorphology}

The seafloor of the survey area north of Kimolos displays a rather complicated relief (Fig. 2). The southern part includes the submarine slopes off Kimolos Island and displays highly irregular morphology with steep slopes, ridges, local highs or mounts and hummocky seafloor close to Kimolos shoreline. This configuration reflects the volcanic origin of the seafloor's substrate of Kimolos volcanic province.

The eastern part of the survey area encompasses the shelf and slope west and south of Sifnos Island. The seafloor displays smooth morphology. A wide shelf extends to the south of Sifnos and passes abruptly to a steep slope facing the northeastern Kimolos shore. The shelf along the western side of Sifnos becomes gradually narrower towards north and passes towards west to a smoothly to moderate steep slope. The morphological characteristics off Sifnos Island reflect the metamorphic origin of the seafloor's substrate.

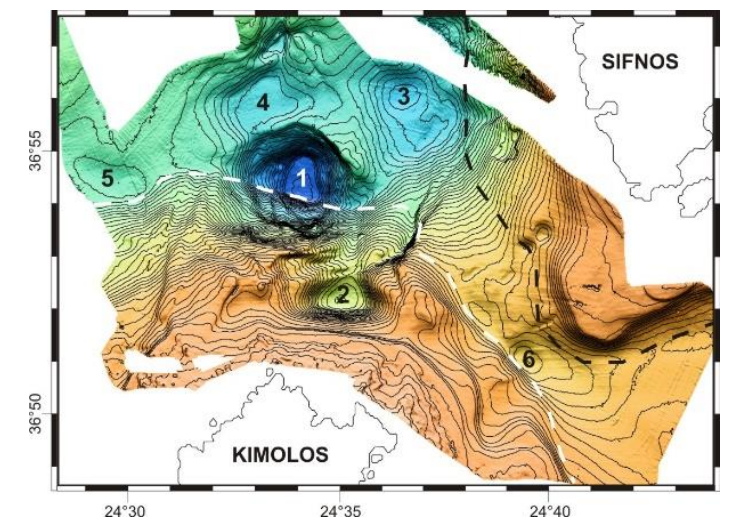

Figure 2 - Numbers 1 to 6: bathymetric depressions. White dashed line: limit of Kimolos volcanic province. Black dashed line: limit of Sifnos metamorphic province. Background: swath bathymetry map.

The northern part of the survey area occupies the southern part of the sedimentary basin which has developed north of Kimolos volcanic province and west of Sifnos metamorphic province. Unlike most flat sedimentary basins, it displays a peculiar relief with local depressions and structural highs spatially alternating. Six noticeable depressions have been labelled with numbers and are shown on the bathymetric map of Fig. 2. Depression Nr. 1 is the deepest and most spectacular among the six, with a maximum depth of $743 \mathrm{~m}$, surrounded by steeply dipping (more than 50\%) slopes. It is located at the foot of the northern slope of Kimolos and the dimensions of its floor, at the $730 \mathrm{~m}$ depth contour, are $1.6 \mathrm{~km}$ in N-S and $1.0 \mathrm{~km}$ in E-W direction. The second well-developed depression is $\mathrm{Nr}$. 2, on the northern slope of Kimolos. The dimensions of its floor, at the $360 \mathrm{~m}$ depth contour, are $0.9 \mathrm{~km}$ and 1.0 $\mathrm{km}$ in N-S and E-W direction, respectively, whilst maximum water depth reaches $370 \mathrm{~m}$.

Apart from the depressions Nr. 1 and 2, four more, locally developed, shallower depressions have been mapped. The three of them, i.e. Nrs. 3, 4 and 5, are located in the basin north of Kimolos, whilst depression Nr. 6 marks the narrowest point of the strait between Kimolos volcanic province and Sifnos metamorphic province.

Seismic reflection profiles show that almost all depressions (except depression Nr. 2) are underlain by thick sedimentary deposits of Plio(?)-Quaternary age. Although processing and interpretation of the seismic data is in progress, preliminary results indicate that the formation of the depressions is the result of active tectonic movements and local transtensional deformation and subsidence. 


\subsection{Sediment grain-size analysis}

Surface sediments in the study area are composed of silt and sand, with minor proportions of clay (Fig. 3). Sand percentages up to 53\% are observed north of Kimolos, exhibiting a decreasing trend towards the north, whilst the highest sand content (63\%) is recorded between Sifnos and Kimolos. Silt is the predominant size class (max. 92\%) with relatively higher values observed at the deepest sector of the study area, i.e. the bathymetric depression and its surroundings. In terms of their textural classification, the sediments vary between sandy silt to silt and are illustrated in the ternary diagram of Fig. 3.
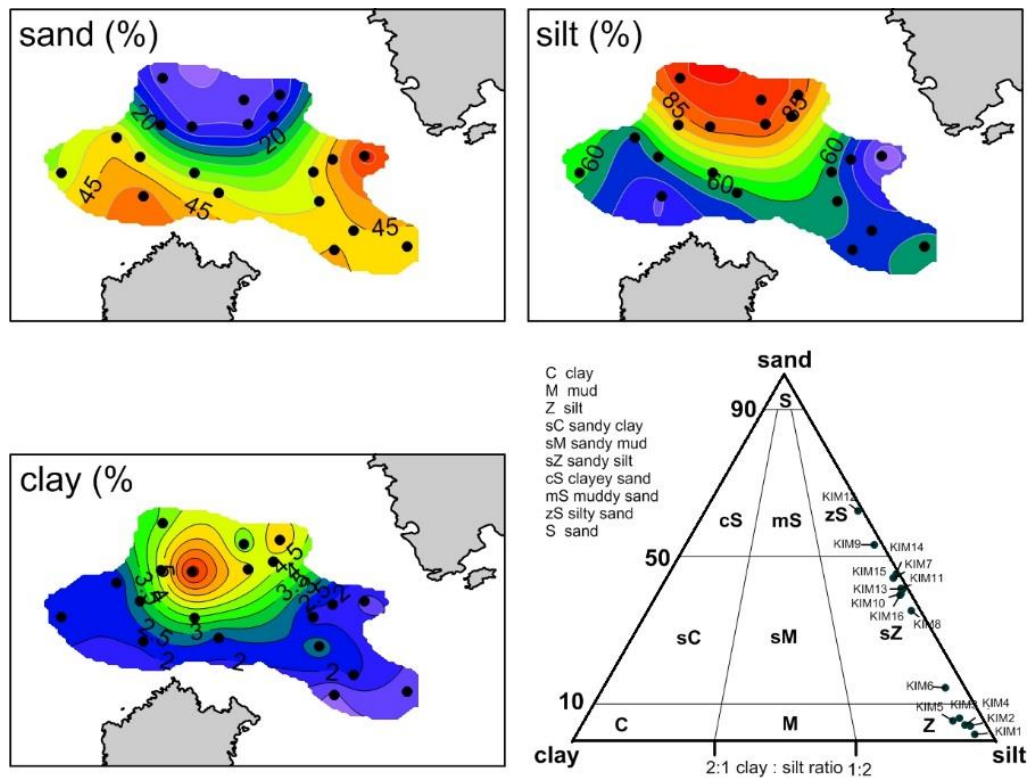

Figure 3 - Spatial distribution of sand, silt and clay percentages. The grain size ternary diagram is also presented (after Folk, 1974).

\subsection{Bulk mineralogy and clay minerals}

The bulk mineralogical composition comprises carbonate minerals (calcite, Mg-calcite, aragonite and dolomite, from 42.6 to $53.9 \%$ in total), quartz (6.4-11.3\%), plagioclase (5.4-15.5\%) and to a lesser extent K-feldspars and clay minerals (illite, chlorite, kaolinite and traces of smectite) (Table 2). Amphiboles, biotite, barite, pyroxenes, epidote, garnet, magnetite, pyrite, serpentine and talc occur as accessory mineral phases (XRD analysis and SEM observations). Terrigenous minerals comprise quartz, plagioclase, $\mathrm{K}$-feldspars, opal-CT, amphiboles and clay minerals. Calcite peaks at the vicinity of the major bathymetric depression, together with chlorite, illite and partly kaolinite (Fig. 4). Plagioclase, K-feldspars, opal-CT, aragonite, and partly kaolinite and quartz show maxima north of Kimolos, displaying decreasing trends towards the north. Dolomite and hornblende appear to be enriched in the Sifnos-Kimolos strait, and Mg-calcite, shows maxima at the NW and E sectors of the study area (Fig. 4).

Based on detailed optical and SEM microscopy observations, several accessory minerals were identified, as allanite and monazite, which are REE-bearing mineral phases. Allanites have noticeable thorium contents (up to $2.7 \%$ ), whereas monazites include relatively high amounts of $\mathrm{REE}$ and thorium contents $(\Sigma \mathrm{REE}+\mathrm{Th}=52-60 \%)$. Ti-bearing minerals include ilmenite, Timagnetite as well as minor rutile and titanite. In particular, unaltered to slightly altered ilmenite and Ti-magnetite formed hypidiomorphic fine and occasionally medium grained crystals with an estimated modal composition of about $0.5 \%$. Barite is present in all examined sediment samples as well as zircon and zinc/copper oxides. 
Table 2 - Mineralogical composition of surface sediments (Cc: calcite, Mg-Cc: magnesium calcite, A: aragonite, D: dolomite, Q: quartz, P: plagioclase, K-F: K-feldspars, Ho: hornblende, O: opal-CT, I: illite, Chl: chlorite, K: kaolinite, Ha: halite).

\begin{tabular}{|l|c|c|c|c|c|c|c|c|c|c|c|c|c|}
\hline Sample & Cc & Mg-Cc & A & D & Q & P & K-F & Ho & O & I & Chl & K & Ha \\
\hline KIM-1 & 27.6 & 18.8 & 2.9 & 0.9 & 7.3 & 6.8 & 5.3 & 0.6 & 2.3 & 10.9 & 8.4 & 4.8 & 3.4 \\
\hline KIM-2 & 26.2 & 19.2 & 4.0 & 0.8 & 7.9 & 7.4 & 6.6 & 0.7 & 2.1 & 9.9 & 8.3 & 4.8 & 2.1 \\
\hline KIM-3 & 26.9 & 16.4 & 3.7 & 0.9 & 7.1 & 9.2 & 6.6 & 0.8 & 2.0 & 10.1 & 7.9 & 5.2 & 3.2 \\
\hline KIM-4 & 27.3 & 17.8 & 3.8 & 0.7 & 7.8 & 7.7 & 5.8 & 0.6 & 1.6 & 10.6 & 8.5 & 4.9 & 2.9 \\
\hline KIM-5 & 26.9 & 19.5 & 2.9 & 0.9 & 6.8 & 6.1 & 5.1 & 0.3 & 2.0 & 13.3 & 8.1 & 4.2 & 3.9 \\
\hline KIM-6 & 27.1 & 22.6 & 3.5 & 0.7 & 6.4 & 6.4 & 5.5 & 0.6 & 1.6 & 11.1 & 6.3 & 4.9 & 3.3 \\
\hline KIM-7 & 19.6 & 27.2 & 5.1 & 1.5 & 7.8 & 8.3 & 5.6 & 0.7 & 2.1 & 9.5 & 7.3 & 3.1 & 2.2 \\
\hline KIM-8 & 21.8 & 19.9 & 4.6 & 0.6 & 8.9 & 11.2 & 6.6 & 0.8 & 3.7 & 8.5 & 6.9 & 4.4 & 2.1 \\
\hline KIM-9 & 22.4 & 8.9 & 10.6 & 0.7 & 8.8 & 15.5 & 8.6 & 0.6 & 2.9 & 10.7 & 4.8 & 3.4 & 2.1 \\
\hline KIM-10 & 23.5 & 10.8 & 7.6 & 0.7 & 8.8 & 11.6 & 9.6 & 1.0 & 4.0 & 7.9 & 6.8 & 5.3 & 2.4 \\
\hline KIM-11 & 19.9 & 21.0 & 6.0 & 1.2 & 9.2 & 8.9 & 4.8 & 1.1 & 2.5 & 12.8 & 7.2 & 3.2 & 2.2 \\
\hline KIM-12 & 24.3 & 16.9 & 9.2 & 2.0 & 8.9 & 12.7 & 2.5 & 1.1 & 0.3 & 11.4 & 4.8 & 3.5 & 2.4 \\
\hline KIM-13 & 20.9 & 24.6 & 7.7 & 1.1 & 9.8 & 5.4 & 4.5 & 0.6 & 2.7 & 8.9 & 6.2 & 4.8 & 2.8 \\
\hline KIM-14 & 27.9 & 8.6 & 9.6 & 1.4 & 11.3 & 12.8 & 7.8 & 1.1 & 2.6 & 5.7 & 5.7 & 4.6 & 0.9 \\
\hline KIM-15 & 25.4 & 13.6 & 7.5 & 1.8 & 9.4 & 12.7 & 5.7 & 0.7 & 1.5 & 8.1 & 6.8 & 4.2 & 2.6 \\
\hline KIM-16 & 24.0 & 18.2 & 5.4 & 1.3 & 9.3 & 12.0 & 6.9 & 1.2 & 1.5 & 7.1 & 5.7 & 4.5 & 2.9 \\
\hline
\end{tabular}

\subsection{Geochemistry of major and minor elements}

Calcium is the major elemental component ( $\mathrm{CaO} 23.1-30.7 \%)$, followed by $\mathrm{Si}, \mathrm{Al}, \mathrm{Mg}$ and $\mathrm{Fe}$ oxides (Table 1). The abundance of biogenic cells and their fragments in the sediments point primarily to a biogenic origin of $\mathrm{Ca}$ and $\mathrm{Mg}$, however, plagioclase, detrital calcite and dolomite are also contributors of those elements. Silicon is typical component of aluminosilicate minerals as well as detrital quartz. The mean Si/Al ratio is 3.45, fairly similar to the average shale (3.41; Turekian and Wedepohl, 1961); some higher values (up to 4.1) are observed between Sifnos and Kimolos islands.

Considering the element spatial distribution patterns (Fig. 5), different provinces are identified: i) $\mathrm{Si}, \mathrm{Al}$ and $\mathrm{K}$ contents are more pronounced north of Kimolos, being associated with more coarsegrained, shallow water sediments; ii) $\mathrm{Fe}, \mathrm{Ti}, \mathrm{Na}, \mathrm{Mg}$ and partly $\mathrm{S}$ exhibit higher contents in the northern sector, which is characterized by finer grain-sizes and deeper waters. It should be noted that $\mathrm{Na}$ is mainly related to halite, due to insufficient removal of sea-salt; and iii) $\mathrm{Ca}$ is more abundant at the western and eastern sectors of the study area, without indicating any clear association with other major elements.

Minor elements demonstrating the highest mean contents are $\mathrm{Mn}\left(1540 \mu \mathrm{g} \mathrm{g}^{-1}\right), \mathrm{Sr}\left(990 \mu \mathrm{g} \mathrm{g}^{-1}\right)$ and $\mathrm{Ba}\left(410 \mu \mathrm{g} \mathrm{g}^{-1}\right)$. According to their spatial distribution patterns (Fig. 6) the following groups are formed: i) the metals $\mathrm{Cr}, \mathrm{Cu}, \mathrm{Ni}, \mathrm{V}, \mathrm{Zn}$ and partly $\mathrm{Pb}$ exhibit highest contents in the northern sector of the area; ii) Mn, Co and partly As also show maxima in the northern sector but also peak at KIM5 sampling site, located at the major depression; iii) $\mathrm{Ba}$ and $\mathrm{Sr}$ decrease in a S-N direction; and iv) $\mathrm{Rb}$ shows double maxima at the northern sector and north of Kimolos.

\subsection{Factor analysis}

In general, variation in sediments' mineralogical and geochemical composition and spatial distribution can be explained by a number of key-factors, i.e. bottom topography and water depth, grain size and other textural characteristics, different provenance, as well as in situ biological and geochemical processes.

The complex sedimentological and geochemical features that were identified in the study area were further investigated by multivariate statistics methods, described hereafter, to gain better understanding on the interrelationships of all variables. Exploratory factor analysis (EFA) is a statistical data-reduction method widely applied in geosciences to allow grouping of correlated variables assuming that an underlying causal model exists. Prior to analysis, the data set was checked 
for outliers (Box-and-Whisker plots and Grubbs test), checked for normality (Kolmogorov-Smirnov test) and, then, transformed to improve normality and symmetry (Box-Cox transformation and ztransformation); a detailed description of the method is given in Karageorgis et al. (2009).
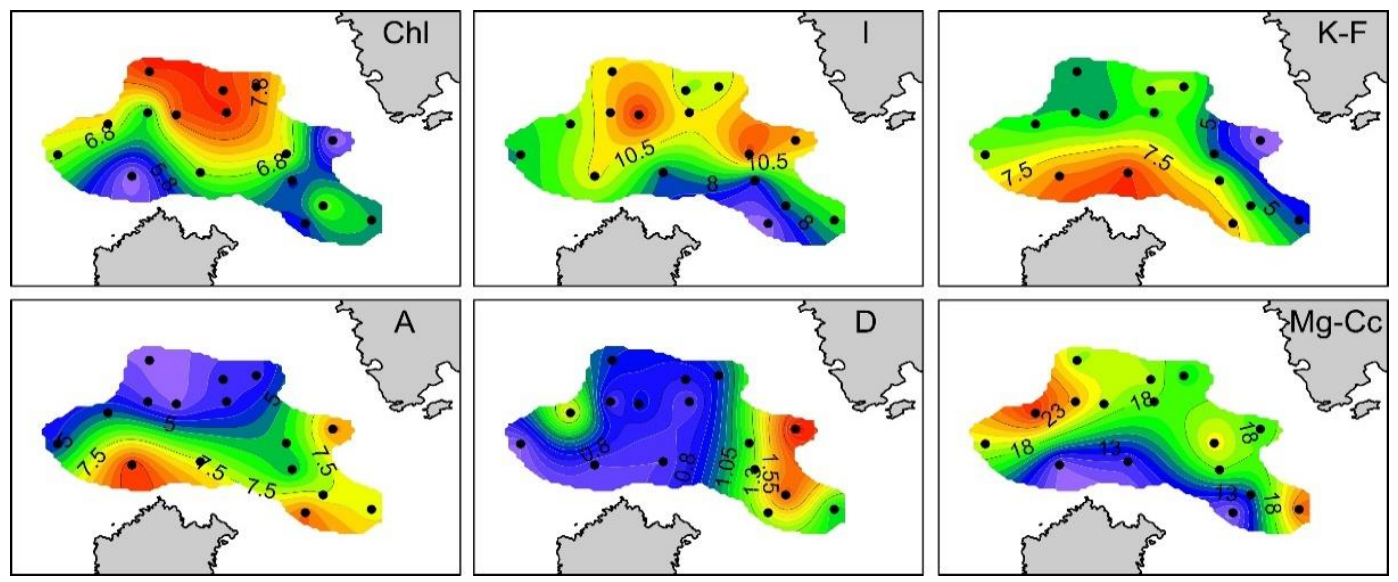

Figure 4 - Spatial distribution of main minerals (\%).

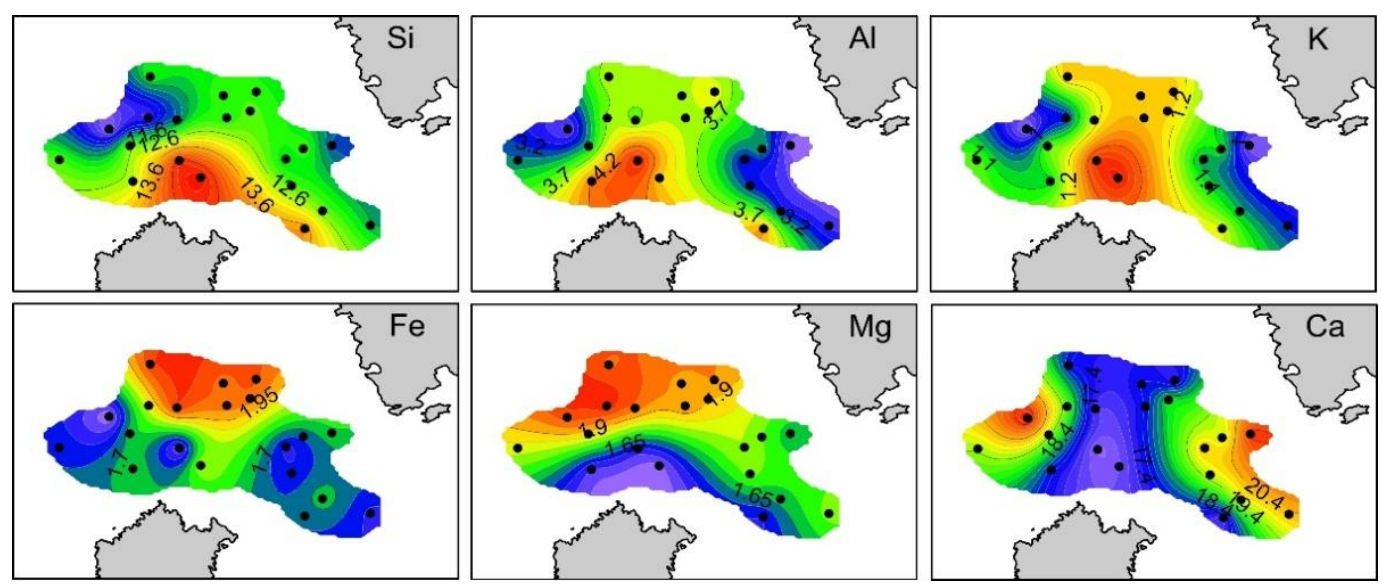

Figure 5 - Spatial distribution of major elements (\%).
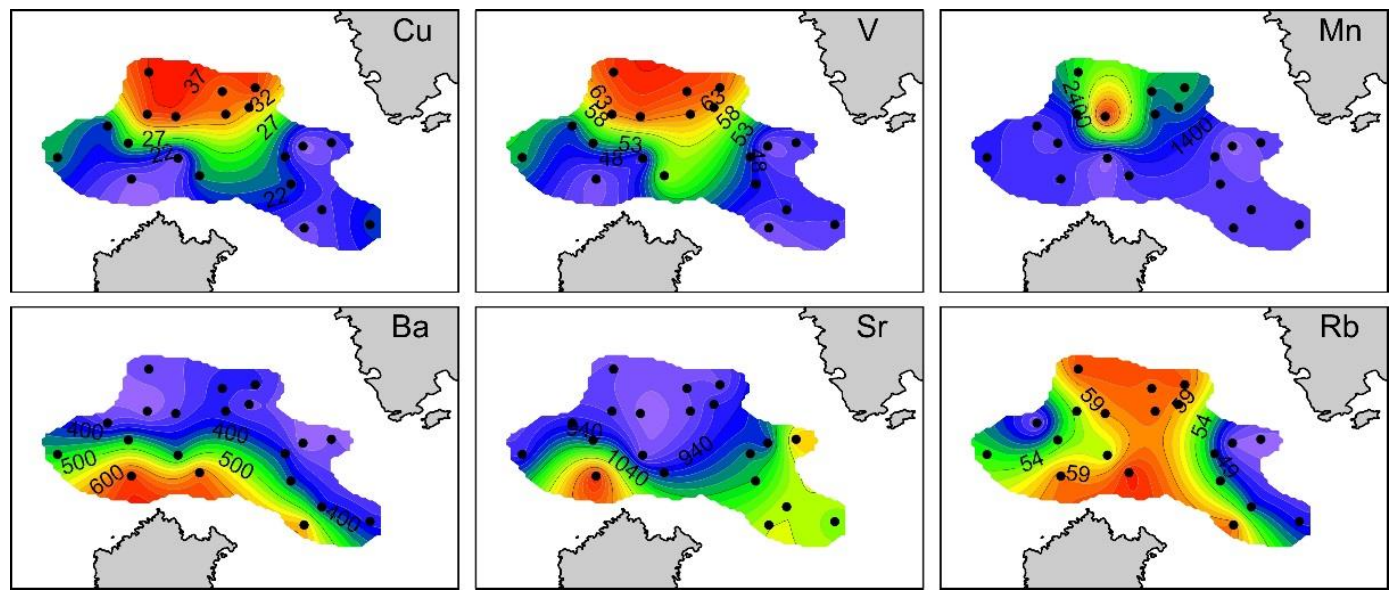

Figure 6 - Spatial distribution of minor elements $\left(\mu \mathrm{g} \mathrm{g}^{-1}\right)$. 
Variables exhibiting low communalities (the squares of correlations) were excluded from EFA and a new model was created. A final 3-factor model solution was selected, which explains $89 \%$ of the total variance (Table 3 ).

Factor $1(60 \%)$ exhibits high loadings for $\mathrm{Mn}, \mathrm{Fe}$ (and $\mathrm{Na}$ ), minor elements $\mathrm{Co}, \mathrm{Cr}, \mathrm{Cu}, \mathrm{V}, \mathrm{Zn}$, clay content and water depth. Factor 1 may be interpreted as Fe-Mn oxides, amorphous and/or crystalline, which are efficient scavengers of numerous metals (Stumm and Morgan, 1996). Manganese is supplied to the ocean either as Mn-oxide coatings on particulate material delivered by wind/rivers or by deeper sediments through diffusion and early diagenesis (Calvert and Pedersen, 2003). In the north Aegean (Sporades basin), Mn oxides occurred as coatings on fine grained calcite particles or quartz (Karageorgis et al., 2005). In the study area, Mn content shows increasing trend towards deeper waters and may be related to lower sedimentation rates, as observed in the Gulf of Lions (Marin and Giresse, 2001). The excess $\mathrm{Mn}$ content in the surface sediments is also documented by the $\mathrm{Mn} / \mathrm{Al}$ ratio, which peaks at the deepest (735 m) KIM-5 sampling site at $1596 \times 10^{-4}$, a value several-fold higher than the average shale $\mathrm{Mn} / \mathrm{Al}$ ratio of $94 \times 10^{-4}$ (Turekian and Wedepohl, 1961), further suggesting a substantial enrichment of the deeper sediments in Mn oxides and associated minor elements. However, Fe/Al ratio varies between 0.32 and 0.64 (mean $0.51 \pm 0.06$ ), which is comparable to the average shale value of 0.59 , denoting minor Fe enrichment. Energetically, Mn oxides are much more favourable electron acceptors than iron oxides or sulfate, thus, in the study area, Mn oxides play a primary role on the adsorption and complexation of various metals.

Table 3 - Factor pattern after Varimax rotation.

\begin{tabular}{|l|l|l|l|}
\hline Variable & \multicolumn{1}{|c|}{ F1 } & \multicolumn{1}{|c|}{ F2 } & \multicolumn{1}{|c|}{ F3 } \\
\hline $\mathrm{Si}$ & -0.286 & 0.881 & -0.238 \\
\hline $\mathrm{Al}$ & 0.146 & 0.841 & 0.024 \\
\hline $\mathrm{Fe}$ & 0.749 & 0.275 & 0.336 \\
\hline $\mathrm{Ti}$ & 0.297 & 0.580 & 0.725 \\
\hline $\mathrm{K}$ & 0.116 & 0.955 & 0.245 \\
\hline $\mathrm{Na}$ & 0.854 & 0.266 & 0.186 \\
\hline $\mathrm{Ca}$ & -0.284 & -0.902 & -0.062 \\
\hline $\mathrm{Mg}$ & 0.549 & -0.440 & 0.601 \\
\hline $\mathrm{Ba}$ & -0.054 & 0.538 & -0.695 \\
\hline $\mathrm{Co}$ & 0.886 & 0.024 & 0.382 \\
\hline $\mathrm{Cr}$ & 0.629 & -0.030 & 0.695 \\
\hline $\mathrm{Cu}$ & 0.836 & 0.025 & 0.506 \\
\hline $\mathrm{Mn}$ & 0.947 & -0.015 & 0.190 \\
\hline $\mathrm{Ni}$ & 0.666 & -0.045 & 0.735 \\
\hline $\mathrm{Rb}$ & 0.634 & 0.749 & -0.021 \\
\hline $\mathrm{Sr}$ & -0.377 & -0.274 & -0.752 \\
\hline $\mathrm{V}$ & 0.784 & 0.167 & 0.564 \\
\hline $\mathrm{Zn}$ & 0.864 & 0.350 & 0.243 \\
\hline $\mathrm{clay}$ & 0.714 & 0.147 & 0.543 \\
\hline $\mathrm{depth}$ & 0.628 & 0.027 & 0.757 \\
\hline
\end{tabular}

Factor 2 explains $24 \%$ of the total variance and exhibits high loadings for $\mathrm{Si}, \mathrm{Al}, \mathrm{K}, \mathrm{Rb}$ and moderate loadings for $\mathrm{Ti}$ and $\mathrm{Ba}$, thus, representing the group of terrigenous aluminosilicates elements, which are inversely loaded to $\mathrm{Ca}$ and $\mathrm{Sr}$, the typical constituents of autochthonous biogenic carbonates. Finally, Factor $3(5 \%)$ with high loadings for $\mathrm{Ti}, \mathrm{Mg}, \mathrm{Cr}$, $\mathrm{Ni}$ and water depth, may be associated 
with the presence of minerals such as amphiboles, chlorite, serpentine and talc, derived from the metamorphic rocks of Sifnos Island, whereas Ti-bearing minerals (ilmenite, rutile and titanite) originate in the volcanic, pyroclastic and granitic rocks of Kimolos. The spatial distribution of those elemental ratios to $\mathrm{Al}$ (not shown) support this notion.

\section{Concluding remarks}

Available grain size, quantitative mineralogical and geochemical data provide a unique opportunity to study sediment distribution patterns and provenance, as they exhibit common attributes. The autochthonous biogenic component is very pronounced, illustrated by calcite, Mg-calcite and aragonite, and explains the geochemical behaviour of the elements $\mathrm{Ca}, \mathrm{Mg}$ and $\mathrm{Sr}$. Calcium in the bulk sediment originates both in the biogenic carbonate minerals but also in the detrital dolomite and plagioclase. For that reason, its spatial distribution does not closely resemble to the distribution patterns of calcite, which is the most abundant mineral. Strontium and aragonite are linearly correlated $\left(\mathrm{R}^{2}=0.871\right)$, suggesting that $\mathrm{Sr}$ substitutes $\mathrm{Ca}$ ions preferentially in aragonite rather than in other carbonate minerals. On the other hand, dolomite clearly originates in the marbles of Sifnos, which are abundant in the island (Matthews and Schliestedt, 1984). Sifnos is also the prime source of chlorite and illite (blue and green schists) and these fine clay minerals settle preferentially into the major bathymetric depression, attracting a variety of chemical elements, which are structural to aluminosilicates and a portion of metals too.

The volcanic formations of Kimolos (Photiadis, 2012) and probably the Kastro and Prassa ignimbrite (Christidis, 2001) are the main sediment contributors in plagioclase, K-feldspars, opal CT, kaolinite and quartz, thus, explaining the distribution patterns of several elements such as $\mathrm{Si}, \mathrm{Al}, \mathrm{K}, \mathrm{Ba}$ and $\mathrm{Rb}$. Manganese oxides and hydroxides, associated with most of the metals $(\mathrm{Co}, \mathrm{Cr}, \mathrm{Cu}, \mathrm{Ni}, \mathrm{V}, \mathrm{Zn})$ due to their high adsorption capacity, appear to be the dominant phase in the northern sector of the study area, including the major depression, but they do not relate to a single mineral phase, most probably due to their amorphous or poorly crystallized nature.

The SE sector of the study area, i.e. the Sifnos-Kimolos strait, is characterized by rather coarsegrained sediments, occurring at depths up to $300 \mathrm{~m}$. On one hand, this is due to the abundance of sand-sized shells and debris of molluscs, but it also implies the presence of strong bottom-currents, which strip out fine-grained sediments. This is in agreement with the early work of Anagnostou et al. (1998) as well as the recent observations of Tripsanas et al. (2016); the latter authors identified several episodes of intense bottom-current activity during the last 80 ka in the South Aegean Sea, associated with climatic changes.

\section{Acknowledgments}

We wish to thank the officers and crew of R/V Aegaeo for their invaluable support during field measurements and sampling during the cruise AEX-2. The research cruise was funded by EU/ESPA, YPOTHER project (351008), realized at IGME in collaboration with HCMR.

\section{References}

Anagnostou, Ch., Richter, D.K., Riedel, D. and Trapp, T., 1998. Recent sediments in the south Cyclades marine area, Aegean Sea, Bull. Geol. Soc. Greece, XXXII/2, 193-203.

Calvert, S.E. and Pedersen, T.F., 1993. Geochemistry of recent oxic and anoxic marine sediments: Implications for the geological record, Mar. Geol., 113, 67-88.

Christidis, G.E., 2001. Formation and growth of smectites in bentonites: A case study from Kimolos Island, Aegean, Greece, Clays and Clay Minerals, 49(3), 204-215.

Folk, R.L., 1974. Petrology of sedimentary rocks, Hemphill, Austin, Texas. 
Karageorgis, A.P., Anagnostou, C.L. and Kaberi, H., 2005. Geochemistry and mineralogy of the NW Aegean Sea surface sediments: implications for river runoff and anthropogenic impact, Appl. Geochem., 20(1), 69-88, doi: 10.1016/j.apgeochem.2004.07.008.

Karageorgis, A.P., Katsanevakis, S. and Kaberi, H., 2009. Use of enrichment factors for the assessment of heavy metal contamination in the sediments of Koumoundourou Lake, Greece, Water Air Soil Poll., 204, 243-258, doi: 10.1007/s11270-009-0041-9.

Marin, B. and Giresse, P., 2001. Particulate manganese and iron in recent sediments of the Gulf of Lions continental margin (north-western Mediterranean Sea): deposition and diagenetic process, Mar. Geol., 172, 147-165.

Matthews, A. and Schliestedt, M., 1984. Evolution of the blueschist and greenschist facies rocks of Sifnos, Cyclades, Greece. A stable isotope study of subduction-related metamorphism, Contrib. Mineral. Petrol., 88, 150-163.

Photiadis, A., 2012. Geological map sheet "Kimolos" scale 1:50.000, IGME, 2012.

Piper, D.J.W. and Perissoratis, C., 2003. Quaternary neotectonics of the South Aegean arc. Mar. Geol., 198, 259-288.

Poulos, S.E., 2009. Origin and distribution of the terrigenous component of the unconsolidated surface sediment of the Aegean floor: A synthesis, Cont. Shelf Res., 29, 2045-2060.

Stumm, W. and Morgan, J.J., 1996. Aquatic Chemistry, Wiley-Interscience, New York.

Tripsanas, E.K., Panagiotopoulos, I.P., Lykousis, V., Morfis, I., Karageorgis, A.P., Anastasakis, G. and Kontogonis, G., 2016. Late Quaternary bottom-current activity in the South Aegean Sea reflecting climate-driven dense-water production, Mar. Geol., accepted manuscript.

Turekian, K.K. and Wedepohl, K.H., 1961. Distribution of the elements in some major units of the earth's crust, Bull. Geol. Soc. Am., 72, 175-192. 